BACTERIOLOGICAL NOMENCLATURE

AND T AXONOMY

\title{
REPORT OF COMMITTEE ON MEDICAL AND VETERINARY MYCOPATHOLOGY
}

Walter J. Nickerson, Chairman

The Special Committee on Medical and Veterinary Mycopathology met four times during the course of the Fifth International Congress of Microbiology. The following members were present:

G. C. Ainsworth, E. A. de Area Leao, F. de Almeida, A. L. Carrion, Amadeau Cury (Secretary), C. W. Emmons, J. E. Mackinnon, W. J. Nickerson (Chairman), P. Negroni, P. Redaelli.

The first meeting was convenedby the Secretary, Dr. Nickerson, who was subsequently elected Chairman, that office having been previously unfilled. Dr. Amadeau Cury was appointed to be a member of the Committee and was subsequently elected secretary. The death of Dr. M. Langeron, former member of the Committee, was observed by a moment of silence in his memory.

The first meeting of the Committee was devoted to a discussion of its aims and functions, and to a review of work accomplished since its formation in 1948. By unanimous vote, the following resolution was adopted and submitted to the Nomenclature Committee of the Congress.

"The Special Committee on Medical and Veterinary $\mathrm{My}$ copathology, which was appointed in 1948 ( after the Copenhagen (ongress), believes that it can serve a very useful and much needed function by considering at an international level various aspects of medical and veteriary mycology.

In addition to questions involving the application of the International Rules of Nomenclature to pathogenic fungi, the Committee would like to consider names of pathogenic fungi which could be recommended for use throughout the world, the standardization of the names of mycotic diseases, the standardization of culture media, and the 
maintenance of culture collections of medical and veterinary importance.

The Committee, therefore, unanimously recommends:

1. That the constitution of the Special Committee on Medical and Veterinary Mycology should be confirmed.

2. That in view of the Committee's interest in the nomenclature of fungi the International Botanical Congress should be invited to consider the formal representation of the Committee on Medical and Veterinary Mycopathology with the Special Committee for Fungi of that Congress. (Dr. C. W. Emmons, a member of the Committee, is already a member of the I. B. C. Special Committee for Fungi. Dr. Emmons might be acceptable to the Botanical Congress as a representative of the Committee. )"

"Le comité spécial de Mycopathologie Médicale et Vétérinaire qui fut organisé en mille neuf cent quarante huit (aprés le Congrés de Copenhague ) croit qu'il peut fort bien jouer un rôle utile et nécessaire en consider ant sur le plan international divers aspects de la mycologie médicale humaine et vétérinaire.

En plus des problêmes concernant l'application des réglements internationaux de nomenclatures aux champignons pathogènes, le comité voudrait considérer quels noms, d'usage universels, pourraient être recommandés pour ces champignons. Le comité aimerait de plus étudier la standardisation des noms de mycoses, la standardisation des milieux de cultures et la possibilité de maintenir des collections de culture d'intérêt médical et vêtérinaire.

Le comité fait donc aux organisateurs de l'Association Internationale de Microbiologie les recommandations suivants: 
B ACTERIOLOGICAL NOMENCLATURE AND TAXONOMY

a. Que la constitution du comité soit confirmée.

b. Que le Congrés International de Botanique soit invité à considérer la collaboration officielle du Comité de Mycopathologie médicale et vétérinaire avec le Comité Special des Fongis de ce Congrés, puisque ces deux comités sont vitalement intéressés dans la nomenclature des champignons."

In the interim between its organization and its first meeting the Committee had agreed by correspondence that a most urgent matter for its consideration would be the nomenclature of fungi pathogenic for man and animals. Therefore, as a basis for discussion, members of the Committee prepared proposals, on the nomenclature of various organisms or groups, presenting in detail the pertinentinformation on the organisms in question. The proposals were mimeographed and sent to all members, who were invited to comment on any or all of the proposals. The comments were collected, sent to the author of the proposal who, in turn, prepared a revised statement that might serve as a basis for deliberation at the V Congress. The following proposals were circulated to the members before the $V$ Congress:

Notes on the Taxonomy and Nomenclature of the Dermatophytes by $G$. C. Ainsworth.

Generic Name for Imperfect Yeasts - Cryptococcus or Torulopsis? by C. E. Skinner.

On the nomenclature of the Etiologic Agents of Chromomycosis by J. E. Mackinnon.

Actinomyces israeli by M. Langeron.

Copies of the three lists of recommended names of animal disease fungi prepared by regional groups were also sent to Members. The lists were:

1. A compilation of names of pathogenic fungi and synonyms prepared by Dr. S. P. Wiltshire of the Imperial Mycological Institute. 
2. Appendix A, Recommendations of the Committee on Medical Mycology of the Mycological Society of Amer ica.

3. Nomenclature of Fungi Pathogenic to Man and Animals, Names recommended for use in Great Britain. Medical Research Council Memorandum No. 23.

On the basis of the above proposals and lists of recommended names, a comparative tabulation was prepared and sent to all members before the $V$ Congress. The 2nd, $3 \mathrm{rd}$ and 4 th meetings of the Committee we re largely devoted to consideration of these nomenclatural questions. On the comparative tabulation mentioned previously, names for 50 organisms were listed; of these, ready agreement was reached on recommending for international use 34 names; 2 other names were agreed upon,subject to author citations being checked. Decision was deferred on 5 names pending the outcome of taxonomic studies known to be in progress. There was a lack of agreement on the nomenclature of 7 organisms arising from questions of taxonomy. Dr. G. C. Ainsworth agreed to summarize the Committee's deliberations on these matters and the summary appended is from his report.

The importance of a central collection devoted to cultures of animal disease fungi was emphasized in the Committee's discussions. The extensive collection in the laboratory of Dr. Area Leao was considered to be well suited for development under his direction into such a central collection to which reference cultures should be sent.

Some consideration was given to, but no action was taken on, the problems of standardization of culture mediafor identification of animal disease fungi, and the nomenclature of mycotic infections. Studies on these problems will be undertaken by members of the Committee for consideration at the next Congress. 
BACTERIOLOGICAL NOMENCLATURE AND TAXONOMY

\section{LIST OF RECOMMENDED NAMES OF FUNGI PATHOGENIC FOR MAN AND ANIMALS}

During the spring of 1950, a comparative tabulation of the tentative lists of names of fungi of medical importance, drawn up by the Mycological Society of America and the Commonwealth Mycological Institute, Kew, and the published Memorandum of the Medical Research Council, was circulated to the Committee for comment. At the $\mathrm{V}$ International Microbiological Congress, Rio de Janeiro, in August 1950 , the consideration of a choice of names from this tabulation, which the Committee could recommend for international use, was the main business at four long committee meetings.

The following names were unanimously accepted:

(The numbers preceding names are those of the 1950 tabula tion.)

4. Aspergillus flavus Link

5. Aspergillus fumigatus Fresenius

6. Aspergillus nigervan Tieghem

9. Candida a 1 b icans (Robin) Berkhout

10. Candida parakrusei (Castellani et Chalmers) Langeron et Guerra

11. Candida tropicalis (Castellani) Berkhout

12. Coccidio ides immitis Rixford et Gilchrist

13. Cryptococcus neoformans (Sanfelice) Vuillemin

14. Epidermophyton floccosum (Harz) Langeron et

15. Histoplasma capsulatum Darling

16. Histoplasma farciminosum (Rivolta) Ciferri et Redaelli

17. Malassezia furfur (Robin) Baillon

18. Microsporum audouini Gruby

19. $\overline{\text { Microsporum }}$ canis Bodin

20. Microsporum gypseum (Bodin) Guiart et Grigoraki

21. Al1escheria boydii Shear; Stat. Conid:= Mono sporium apiospermum Saccardo

23. Nocardia asteroides (Eppinger) Blanchard

24. Nocardia caprae (Silberschmidt) Emmons 
25. Nocardia madurae (Vincent) Blanchard

27. Nocardia tenuis Castellani

30. Phialophoraverrucosa Medlar

31. Pityrosporum ovale (Bizzozero) Castellani et Chalmers

32. Rhinosporidium seeberi (Wernicke) Seeber

33. $\frac{\text { Sporotrichum schencki }}{\text { Matruchot }}$ (Hektoenet Perkins)

34. Trichophyton concentricum Blanchard

36. Trichophyton epilans Boucher et Mengin Syn. Trichophyton flavum Bodin (38)

37. Trichophyton ferrugineum (Ota) Talice

40. Trichophyton mentagrophytes (Robin) Blan-

41. Trichophyton megnini Blanchard

44. Trichophyton rubrum (Castellani) Ota

45. Trichophyton sabouraudi Blanchard

46. Trichophyton schoenleini (Lebert) Langeron et Milochevitch

48. Trichophyton tonsurans Malmsten

49. Trichophyton violaceum Sabouraud

Dr. Negroni agreed to annotate 23 , N. as te roides. It was also agreed that 27 and 32 should be annotated to the effect that the fungi have not been cultured.

The following two names were accepted, subject to the author citations being checked:

26. Nocardia minutissima

50. Trichosporon beigelii

Deleted from the list:

22. Monosporium sclerotiale Pepere

No final decision was reached on:

1. Absidia corymbifera (Cohn) Saccardo et Trotter

It was agreed that this name, as a name, was unobjectionable. The taxonomic position of this fungus was considered by 
some members to be uncertain and,at the suggestion of Dr. Emmons, it was agreed to defer a decision until after the publication of a monograph on Mucor by Prof. Victor Cutter of Yale University.

2. Actinomyces bovis Harz and 3 . Actinomyces

There was general agreement that the forms attacking man and cattle would probably prove to be distinct and a decision was deferred pending the results of work on this problem known to be in progress.

7. Blastomyces brasiliensis and 8. Blastomy ces dermatitidis

Lack of time prevented discussion of these names about which Dr. Area Leao will make proposals to the Committee.

28. Phialophora compacta (Carrion) Redaelli et Ci-

29. Phialophora pedrosoi (Brumpt)RedaellietCifer -

These two names gave the Committee much trouble in spite of the lucid and informative papers by Dr. Carrion and Prof. Mackinnon setting out the evidence for and against the various issues involved.

The nomenclatural facts appear to be undisputed and,given the taxonomy to be adopted, names in strict accordance with the International Rules of Nomenclature are available.

In Dr. Carrion's view, the species $P$. pedrosoi could be most naturally accommodated in the genus Fonsecaea. Other members felt that this distinction would be difficult to maintain. It was finally decided to adopt $\mathrm{Phi}$ a lophor a in the wide sense for the time being and Dr. Carrion agreed to annotate these names.

Similarly, lack of agreement on classification led to deci- 
Page 150

INTERNATIONAL BULLETIN

sions being deferred on:

35. (The faviform Trichophytons)

39. Trichophyton interdigitale Priestly

42. Trichophyton persicolor Sabouraud

43. Trichophyton quinckeanum (Zopf) Macleod et

47. Trichophyton sulphureum Colcott Fox 